\title{
AKTUALISASI PERAN PEMIMPIN NASIONAL DALAM PENGEMBANGAN SUMBER DAYA MANUSIA BIDANG PARIWISATA
}

\section{ACTUALIZATION OF THE NATIONAL LEADER ROLE IN HUMAN RESOURCE DEVELOPMENT IN TOURISM}

\author{
Sri Langgeng Ratnasari \\ Fakultas Ekonomi Universitas Riau Kepulauan \\ Jl. Batu Aji Baru No. 99 Batam 29432 \\ E-mail: sarisucahyo@yahoo.com
}

\begin{abstract}
Abstrak
Pariwisata di Indonesia merupakan salah satu hal yang belum dikelola secara optimal, salah satunya karena sumber daya manusia di bidang pariwisata masih kurang dan sangat dibutuhkan pengembangannya. Oleh karena itu, peran Kepemimpinan Nasional diperlukan untuk mengembangkan sumber daya manusia di sektor pariwisata. Potensi pariwisata di Indonesia sangat besar, namun belum dimanfaatkan dengan optimal, hal ini dapat dilihat dari kontribusi pariwisata yang masih kecil. Untuk meningkatkan kontribusi pariwisata yang terpenting adalah sumber daya manusia, karena hanya sumber daya manusia yang dapat mengelola potensi alam dan budaya Indonesia yang sangat besar namun belu m dimanfaatkan secara optimal.
\end{abstract}

Kata Kunci: Pengembangan, Su mber Daya Manusia, Pimpinan Nasional, Pariwisata

\section{Abstract}

Tourism in Indonesia is one area that has not been managed optimally, one of them because of human resources in the field of tourism is still lacking and much needed development. Therefore, the National Leadership role is needed to develop human resources in tourism sector. The potential of tourism in Indonesia is very large, but not yet optimally utilized, this can be seen from the contribution of tourism is still small. To increase the contribution of tourism is the most important is the human resources, because the potential of nature and culture of Indonesia is very large but not yet optimally utilized.

Keywords: Development, Human Resources, National Leaders, Tourism

\section{PENDAHULUAN}

Peran Pemimpin Nasional Dalam Pengembangan Sumber Daya Manusia di bidang Pariwisata sangat penting, karena peran penting pemimpin nasional dihadapkan pada salah satu persoalan bangsa yaitu masalah pengembangan sumber daya manusia di bidang pariwisata yang sampai saat ini masih belum optimal. Kekurangan sumber daya manusia di bidang pariwisata di semua sektor masih cukup tinggi, akhirnya menjadi peluang bagi sumber daya manusia di bidang pariwisata dari negara lain untuk mengambil alih. Hal ini dapat kita 
lihat promo wisata dari negara-negara lain dengan tujuan wisata ke Indonesia, dengan biaya mata uang negara tersebut dan seluruh pengelolaan dilakukan oleh mereka. Berdasarkan kenyataan itu maka sangat diperlukan peran pemimpin nasional untuk berperan dalan pengembangan sumber daya manusia di bidang pariwisata agar lebih berdaya guna dan mengoptimalk an peran anak bangsa di negaranya sendiri.

Kepemimpinan adalah suatu fenomena kemasyarakatan yang sangat berpengaruh terhadap kelangsungan hidup suatu bangsa dalam menata. Kehidupan berbangsa dan bernegara. Selain itu kepemimpinan juga merupakan salah satu fungsi strategis yang dapat mendorong terwujudnya cita-cita, aspirasi, dan nilai-nilai yang berkembang dalam masyarakat karena adanya interaksi antara pemimpin dan yang dipimpin, (Lemhannas, 2016).

Kepemimpinan berasal dari kata pemimpin yang dibentuk dari kata dasar pimpin yang berarti tuntun, bimbing. Pimpinan, adalah hasil kerja memimpin, dan kepemimpinan, merupakan sistem atau hal, cara, hasil kerja pemimpin, pemimpin adalah orang yang memimpin (Badudu, 2011:1062). Kepemimpinan (leadership) dapat juga diartikan sebagai kemampuan yang ada dari seseorang untuk mempengaruhi, menggerakkan, dan mengarahkan orang lain untuk mencapai suatu tujuan. Kepemimpinan Nasional adalah merupakan sistem, struktur dan kultur pemimpin nasional, (Lemhannas, 2016). Kepemimpinan menurut Gaspersz (2007) adalah kemampuan positif mempengaruhi orang dan sistem untuk memberikan dampak yang berguna dan mencapai hasil-hasil yang diinginkan.

Berkaitan dengan bangsa dan negara maka kepemimpinan ini dimaksudkan sebagai Kepemimpinan Nasional yang dapat didefinisikan sebagai kelompok pemimpin bangsa pada segenap strata kehidupan nasional di dalam setiap gatra (Astagatra) pada bidang/sektor profesi baik di supra struktur, infra struktur dan sub struktur, formal dan informal yang memiliki kemampuan dan kewenangan untuk mengarahkan/mengerahkan segenap potensi kehidupan nasional (bangsa dan negara) dalam rangka pencapaian tujuan nasional berdasarkan Pancasila dan UUD 1945 serta memperhatikan dan memahami perkembangan lingkungan strate gis guna mengantisipasi berbagai kendala dalam memanfaatkan peluang (Lemhannas, 2016)

Dari deiinisi tentang Kepemimpinan dan Kepemimpinan Nasional menegaskan kepada kita bahwa begitu penting dan strategis posisi dan kedudukan dari seorang pemimpinan dalam berkehidupan di organisasi apalagi dalam kehidupan berbangsa, bernegara dan bermasyarakat. Posisi atau kedudukan para pemimpin sangat menentukan apakah tujuan organisasi, bangsa dan negara mereka dapat dicapai atau tidak. 
Peran pemimpin sangat besar terhadap kinerja, hal ini terbukti pada hasil penelitian Wasla dan Ratnasari (2016).

Tujuan nasional negara Republik Indonesia dapat kita lihat sebagaimana tertuang dalam pembukaan UUD NRI Tahun 1945 di alinea ke empat yang secara tegas dinyatakan bahwa negara melindungi segenap bangsa Indonesia, memajukan kesejahteraan umum, mencerdaskan kehidupan bangsa dan ikut melaksanakan ketertiban dunia yang berdasarkan kemerdekaan, perdamaian abadi dan keadilan sosial.

Dari teori Kepemimpinan dikaitkan dengan Kepemimpinan Nasional banyak tipe-tipe atau style Kepemimpinan dengan ciri-ciri khusus dari Kepemimpinan itu sendiri. Setidaknya dikenal ada Kepemimpinan Visioner, Kepemimpinan Negarawan, Kepemimpinan Kontemporer, Kepemimpinan Transaksional dan Kemepimpinan Informal.

Salah satu persoalan negara dan bangsa saat ini dan di masa yang akan datang adalah masalah Pariwisata. Banyak para pakar dan ahli pariwisata serta organisasi pariwisata yang memberikan batasan atau pengertian dari pariwisata tetapi untuk menyatukan pengertian, maka dalam esai ini menggunakan pengertian pariwisata menurut Undang - Undang No. 10 Tahun 2009 Pasal 1 butir 3 dimana yang dimaksud dengan pariwisata adalah berbagai macam kegiatan wisata dan didukung berbagai fasilitas serta layanan yang disediakan oleh masyarakat, pengusaha, pemerintah dan pemerintah daerah, (Febriantini 2012:22)

Pengertian kepariwisatan menurut Undang - Undang No. 10 tahun 2009 pasal 1 angka 4 adalah keseluruhan kegiatan yang terkait dengan pariwisata dan bersifat multidimensi serta multidisiplin yang muncul sebagai wujud kebutuhan setiap orang dan negara, serta interaksi antara wisatawan dan masyarakat setempat, sesama wisatawan, pemerintah, pemerintah daerah dan pengusaha, (Febriantini, 2012:23).

Menurut Yoeti dalam Febriantini (2012:24) Pariwisata adalah suatu perjalanan yang dilakukan untuk sementara waktu yang diselengarakan dari suatu tempat ke tempat yang lain dengan maksud tujuan bukan untuk berusaha atau mencari nafkah di tempat yang dikunjungi, tetapi semata-mata menikmati perjalanan tersebut untuk memenuhi kebutuhan/keinginan yang bermacam-macam.

Salah satu yang sangat berhubungan dengan pariwisata yaitu obyek wisata yang mempunyai pengertian yaitu tempat atau keadaan alam yang memiliki sumber daya wisata yang dibangun dan dikembangkan sehingga mempunyai daya tarik dan diusahakan sebagai tempat yang dikunjungi wisatawan. Obyek wisata dapat berupa obyek wisata alam seperti 
gunung, danau, sungai, pantai, laut atau berupa obyek wisata bangunan seperti museum, benteng, situs peninggalan sejarah dan lain-lain. Berdasarkan definisi diatas maka pariwisata merupakan aktifitas manusia untuk sementara waktu yang dilakukan secara sadar dari satu tempat ke tempat lain dengan tujuan untuk bersenang-senang bukan mencari nafkah dengan berbagai kegiatan pariwisata, (Pangestu, 2015:24).

Menurut pendapat Pangestu (2015:25) terdapat 7 (tujuh) permasalahan pariwisata di Indonesia, yaitu:

1. Sarana dan Prasarana.

2. Sumber Daya Manusia.

3. Komunikasi dan Publisitas.

4. Kebijakan dan Peraturan yang berlaku dalam lingkungan negara dan daerah.

5. Teknologi Informasi.

6. Kesiapan Masyarakat.

7. Investasi yang belum banyak berkembang di daerah.

Dari latar belakang di atas maka penulis merumuskan beberapa masalah-masalah yang harus diselesaikan antara lain:

1. Sistem Kepariwisataan.

2. Pengembangan Pariwisata.

3. Keterkaitan antara pariwisata dengan wisatawan dalam dunia pariwisata.

4. Manfaat pariwisata dalam pembangunan ekonomi negara.

5. Solusi-solusi yang perlu direkomendasikan dalam pengembangan dunia kepariwisataan.

6. Pariwisata penting bagi negara Indonesia.

Permasalahan pariwisata tersebut di atas harus segera diminimalisir, oleh karena itu diperlukan aktualisasi peran pemimpin nasional dapat mewujudkan pengembangan pariwisata.

\section{METODOLOGI}

Penelitian ini menggunakan metode studi literatur dengan menggunakan analisis kualitatif dan deskriptif. Hal ini untuk menguraikan dan menjelaskan keterkaitan penelitian terdahulu dengan penelitian saat ini, sehingga penelitian terdahulu dapat digunakan sebagai referensi dan melengkapi penelitian yang sekarang. 


\section{PEMBAHASAN}

Kepemimpinan adalah kemampuan para pemimpin mempengaruhi para bawahannya sehingga para bawahannya secara sukarela melaksanakan pekerjaan sesuai dengan keinginan pemimpinnya. Kepemimpinan dapat diartikan sebagai kemampuan mendorong sejumlah orang (dua orang atau lebih) agar bekerjasama dalam melaksanakan kegiatan-kegiatan yang terararh pada tujuan bersama, Amarazisa (2016: 2).

Kepemimpinan mempengaruhi kinerja, hal ini terbukti pada penelitian Darmayanti dan Ratnasari (2016), Ashrahenny dan Ratnasari (2016). Oleh karena itu kepemimpinan harus dioptimalkan agar kinerja menjadi lebih baik.

Dewasa ini maupun pada masa yang akan datang, kebutuhan untuk berwisata akan terus meningkat seiring dengan pertambahan jumlah penduduk dunia, serta perkembangan penduduk dunia yang semakin membutuhkan refressing akibat dari semakin tingginya kesibukan kerja.

Faktor-faktor pendorong pengembangan pariwisata di Indonesia menurut Spilane adalah: 1) berkurangnya peranan minyak bumi sebagai sumber devisa negara jika dibanding dengan waktu lalu; 2) merosotnya nilai eksport pada sektro nonmigas; 3) adanya kecenderungan peningkatan pariwisata secara konsisten; 4) besarnya potensi yang dimiliki oleh bangsa Indonesia bagi pengembangan pariwisata, Budian (2016).

Situasi dan kondisi sosioekonomi Indonesia saat ini, yang memperlihatkan bahwa semakin berkurangnya lahan pertanian dan lapangan pekerjaan lainnya serta semakin rusaknya lingkungan akibat kegiatan manufaktur dan kegiatan-kegiatan ekonomi lainnya yang mengeksploitasi sumberdaya alam, maka pariwisata perlu dikembangkan sebagai salah satu sumber produksi andalan. Sektor pariwisata selain dapat meningkatkan pertumbuhan ekonomi, juga tidak merusak lingkungan bahkan sebaliknya merangsang pelestarian lingkungan hidup. Hal ini dapat dimengerti karena pengembangan pariwisata tidak dapat dipisahkan dari lingkungan hidup sebagai salah satu sasaran atau obyek wisata.

Dari laporan dan analisis World Tourism Organization (WTO) diperoleh bahwa sumbangan pariwisata amat berarti bagi penciptaan lapangan kerja. Disebutkan bahwa dari setiap sembilan kesempatan kerja yang tersedia secara global saat ini, satu diantaranya berasal dari sektor pariwisata. Selain itu, pariwisata dapat membuka pasar baru bagi produksi pertanian dan hasil kerajinan rumah tangga yang masih tradisonal maupun usaha-usaha jasa 
seperti tukang pijit, penginapan, transportasi dan guide yang dengan sendirinya membuka peluang kerja baru bagi para pencari kerja yang terus meningkat setiap tahun, serta meningkatkan output negara.

Dari berbagai sumber informasi dan surat kabar, diberitakan bahwa Indonesia memiliki banyak potensi di daerah-daerah yang belum dikembangkan atau dijadikan daerah tujuan wisata (DTW). Selain itu, Indonesia dengan keragaman suku, agama dan ras (SARA) yang memiliki kebudayaan yang berbeda-beda, berupa tari-tarian dan upacara-upacara adat juga merupakan hal yang sangat potensial bagi pengembangan pariwisata. Memang diakui bahwa dengan keragaman SARA tersebut juga mengandung potensi konflik yang seringkali dapat menimbulkan kerusuhan sosial. Karena itu dalam rangka pengembangan pariwisata, selain terdapat sejumlah potensi yang dapat diandalkan, juga terdapat sejumlah hal yang dapat menjadi kendala.

Adapun kendala-kendala yang akan dihadapi dalam pengembangan pariwisata, antara lain adalah: pertama, sering timbulnya konflik dan kerusuhan sosial serta situasi dan konsisi politik yang masih memanas, berakibat pada kurang terjaminnya keamanan bagi para wisatawan.

Kedua, rendahnya mutu pelayanan dari para penyelenggara pariwisata, persaingan yang tidak sehat diantara para penyelenggara pariwisata serta kurangnya pemahaman terhadap pentingnya perlindungan konsumen yang sangat ditekankan di Eropa, Amerika dan Australia, merupakan kendala yang sangat menghambat pariwisata di Indonesia.

Ketiga, rendahnya kesadaran masyarakat tentang pentingnya pengembangan pariwisata merupakan kendala. Sebab banyak rencana pengembangan yang gagal karena kurang mendapat dukungan dari masyarakat akibat rendahnya kesadaran tersebut.

Keempat, kurangnya modal dan rendahya sumberdaya manusia, terutama tenaga yang terampil dan profesional dalam hal manajerial di bidang pariwisata merupakan kendala yang seringkali muncul terutama pada negara-negara berkembang, termasuk Indonesia.

Kelima, sistem transportasi yang belum memadai seringkali menjadi kendala dalam pariwisata yang perlu ditinjau kembali, untuk meningkatkan pelayannya dari segi kualitas maupun kuantitasnya.

Keenam, pengelolaan pariwisata yang bersifat top-down merupakan salah satu kendala yang banyak menghambat pariwisata, terutama pada masa Orde Baru yang terlalu otoriter dan sentralistis. Selama ini, banyak DTW yang tidak dikembangkan karena berbagai keterbatasan 
dari pemerintah pusat, sementara itu pihak swasta dan pemerintah daerah harus menunggu petunjuk dari pemerintah pusat.

Adapun beberapa hal yang dapat menjadi peluang bagi pengembangan pariwisata saat ini, antara lain adalah: pertama, turunnya nilai mata uang rupiah terhadap dollar, dapat memicu meningkatnya jumlah wisatawan. Pernyataan ini dapat dibenarkan karena dengan turunnya nilai mata uang rupiah memungkinkan biaya-biaya yang dikeluarkan wisman jauh lebih rendah dibanding sebelumnya. Dengan demikian hal ini merupakan peluang yang akan dimanfaatkan oleh wisman maupun penyelenggara pariwisata untuk mengembangkan pariwisata dengan lebih mudah.

Kedua, adanya kecenderungan pihak wisawan asing dewasa ini untuk berwisata dalam dimensi tradisonal, seperti mengunjungi desa-desa yang memiliki keunikan baik untuk sekedar mengunjungi maupun untuk wisata ilmiah. Kecenderungan ini harus dimanfaatkan sebaik-baiknya oleh Indonesia yang masih memiliki banyak desa tradisonal serta berbagai obyek penelitian. Peluang ini selain kurang membutuhkan modal yang besar, wisata ilmiah juga dapat memberikan kontribusi ilmiah bagi Indonesia.

Ketiga, jumlah penduduk Indonesia yang jumlahnya kurang lebih 250 juta, juga merupakan peluang pasar yang baik selain para wisatawan asing.

Keempat, adanya kecenderungan perkembangan ilmu pengetahuan dan teknologi (iptek), transportasi, komunikasi dan informasi yang terus meningkat dapat membuka peluang bagi pengembangan pariwisata. Walaupun mungkin kondisi Iptek, transportasi, dan lain-lain tersebut, saat ini belum memadai tetapi kecenderungan kemajuan telah memberikan kemungkinan bahwa di waktu yang akan datang, akan lebih baik. Dengan kemajuan komunikasi, transportasi dan informasi serta semakin maraknya pembangunan lembagalembaga pendidikan pariwisata di seluruh Inodensia, diharapkan dapat mempersiapkan SDM yang lebih baik serta membuka peluang yang luas untuk bekerjasama dengan berbagai pihak di dalam dan di luar negeri, terutama antara antara DTW dengan negara-negara yang potensial.

Walaupun telah terbuka peluang-peluang sebagaimana dikemukakan di atas, pengembangan pariwisata pada saat ini maupun yang akan datang akan diperhadapkan pada tantangan-tantangan, sebagai berikut:

Pertama, adanya berita-berita tantang kerusuhan, kebakaran hutan, dan kondisi lain yang kurang baik di Indonesia cukup menjadi komoditas yang laku dijual oleh negara-negara 
yang kurang senang dengan Indonesia. Hal ini merupakan tantangan bagi Indonesia untuk segera menciptakan keamanan. Keamanan merupakan hal yang mutlak dibutuhkan oleh wisatawan baik dari dalam maupun luar negeri. Karena itu diharapkan adanya kerjasama yang baik antara pemerintah dengan seluruh komponen bangsa dalam menciptakan keamanan.

Kedua, sistem informasi yang kurang memadahi juga tantangan yang perlu mendapat perhatian serius dalam pengelolaan pariwisata. Hal ini menjadi penting agar pengalaman masa lalu tidak terulang. Akibat sistem informasi yang kurang memadahi pandangan dunia terhadap Indonesia menjadi miring, celakanya lagi ketika Jakarta atau daerah-daerah tertentu rusuh, dunia menganggap bahwa seluruh Indonesia rusuh sehingga mengeluarkan larangan berkunjung ke Indonesia. Padahal DTW bukan hanya ada satu di Indonesia, dan belum tentu semua DTW mengalami kerusuhan secara serentak. Untuk itu maka diperlukan suatu sistem informasi yang profesional, mantap visinya serta terampil dan cekatan dalam gerak langkahnya. Sistem informasi ini antara lain bertugas untuk memberikan klarifikasi, sekaligus secara proaktif menyiapkan dan memberikan informasi tentang obyek wisata, kesiapan sarana, prasarana dan lain-lain. Selain itu, juga dapat dimanfaatkan untuk mempromosikan pariwisata di Indonesia ke negara-negara lain.

Ketiga, masalah SDM merupakan tantangan yang cukup berat bagi pengembangan pariwisata, karena SDM sangat menentukan segala sesuatu yang perhubungan dengan pariwisata. Pariwisata sangat mementingkan profesionalisme baik dalam pengelolaan investasi maupun dalam bidang perhotelan, transportasi, komunikasi dan informasi. Selain itu, walaupun pariwisata telah membuka peluang pasar bagi sektor-sektor lain, akibat dari rendahnya SDM peluang tersebut tidak dapat dimanfaatkan secara optimal. SDM yang rendah dapat menyebabkan mutu barang-barang kerajinan menurun, teknik pemasaran kurang tepat, kurang tepat membaca trend pasar, dan lain-lain. Sehubungan masalah SDM

Keempat, akibat rendahnya SDM dan kurangnya modal dalam negeri akan membuka kemungkinan bahwa pariwisata akan dikuasai oleh pihak asing yang memiliki SDM yang lebih baik dan lebih siap dari segi modal. Untuk itu dibutuhkan upaya-upaya khusus untuk menghindari hal tersebut.

Kelima, belum meratanya arus penerimaan wisatawan, di mana ada DTW tertentu sangat ramai dikunjungi wisatawan sementara itu DTW yang lain sangat sepi. Peristiwa ini mengindikasikan bahwa selain kurang menarik, dapat terjadi karena belum diketahui oleh wisatawan. Tantangan ini perlu dihadapi antara lain dengan meningkatkan promosi dan 
melakukan upaya-upaya tertentu agar DTW yang kurang menarik menjadi DTW yang senangi oleh para wisatawan.

Keenam, adanya kemungkinan pariwisata dapat merusak budaya, seperti pergeseran nilai upacara adat yang dapat mengarah kepada komersialisasi, timbulnya industri seks, dan sebagainya. Hal ini harus diwaspadai dengan agar keutuhan dan nilai-nilai budaya tetap diperhatikan.

Pengembangana adalah salah satu bagian manjemen yang menitik beratkan pada implementasi potensi budaya harus dilaksanakan dengan rentang waktu, berapa langka sistematis yang dapat mengarah pada pencapaian hasil,dan hasil yang dicapai diharapkan pada perencanaan manajeman dengan kegiatan yang sangat spesetif untuk mencapai tujuaan visi, tujuan, dan sasaran dari rencana tersebut.

Suwantoro menyatakan pengembangan bertujuan untuk mengembangkan produk yang pelayanan yang berkualitas, seimbang, bertahan. Berdasarkan definisi di atas, yang dimaksud dengan strategi pengambangan adalah upaya-upaya yang dilakukan dengan tujuan untuk memajukan, memperbaiki, dan meningkatkan kondisi kepariwisataan suatu obyek dan daya tarik wisata sehingga mampu menjadi mapan dan ramai untuk dikunjungi oleh wisatawan serta mampu memberikan suatu manfaat baik bagi masyarakat di sekitar obyek dan daya tarik dan lebih lanjut akan menjadi pemasukan bagi pemerintah. Ada lima pendekatan dalam pengembangan, diatara lima pendekatan tersebut, yang dapat menitikberatkan dalam penulisan ini adalah (the community approach) empat diantaranya diindetifikasikan oleh Getz (2007), dan satu tambahan oleh Page (2005).

Empat kelompok pendekatan yang diidentifikasikan Getz (20077) dalam Biduan (2016) adalah:

1. Boosterm: adalah suatu pendekatan sederhana yang melihat pariwisata sebaga suatu atridut positif untuk suatu tempat dan penghuninya masyarakat setempat tidak dilibatkan dalam proses perencanaan daya dukung wilayah tidak cukup dipertimbangkan.

2. The Economic-indusry approach: adalah pendekatan pengembangan yang tujuantujuan ekonomi lebih didahulukan dari tujuan-tujuan sosial dan lingkungan, yaitu dengan menjadikan pengalaman-pengalamanpengunjung dan tingkat kepuasan sebagai sasaran-sasaran utama. 
3. The Physical-Spatial Approach: pendekatan ini didasarkan pada tradisi "penggunaan lahan” geografi. Strategi-strategi pengembangan berdasarkan perencanaan yang berbeda-beda melalui prinsip-prinsip keruangan digunakan di sini, misalnya pengelompokan pengunjung disatu kawasan, dan pemecahan-pememcahan untuk menghindari kemungkinan terjadinya konfik. Hamya satu kritikan bagi pendekatan ini adalah masih kurang mempertimbangkan dampak sosial dan kultural dari pengembangan wisata.

4. The Comunity Approah: pendekatan ini lebih menekankan pada pentingnya keterlibatan maksimul dari masyarakat setempat di dalam proses pengembangan. Pendekatan ini menganggap penting suatu pedoman pengembangan yang dapat diterima secara sosial (socially acceptable).

Oleh karena itu pendekatan yang dilakukan adalah menekankan kepentingan pada manfaat-manfaat sosial yang kultural bagi masyarakat lokal bersama-sama termasuk di dalam pertimbangan ekonomi dan lingkingan.

Berdasarkan potensi dan peluang yang ada, maka pengembangan pariwisata perlu dilakukan dalam rangka meningkatkan pertumbuhan ekonomi dengan pemberdayaan ekonomi rakyat. Dalam kerangka itu pariwisata perlu mengembangkan paket-paket wisata baru seperti agrowisata atau ekowisata. Jenis wisata semacam ini selain tidak membutuhkan modal yang besar juga dapat berpengaruh langsung bagi masyarakat sekitar. Masyarakat dapat diikutsertakan dan keuntungan yang diperolehpun dapat dirasakan oleh masyarakat sekitar. Hal yang paling penting adalah pengembangan sumber daya manusia agar dapat mengelola sumber daya di bidang pariwisata di Indonesia, baik pariwisata alam, budaya, dan religious.

\section{KESIMPULAN DAN SARAN}

\section{Kesimpulan}

Berdasarkan pendahuluan dan pembahasan maka dapat ditarik simpulan sebagai berikut:

1. Sistem Kepariwisataan pada saat ini belum terigtegrasi secara nasional.

2. Pengembangan Pariwisata masih belum optimal dan harus dioptimalkan.

3. Keterkaitan antara pariwisata dengan wisatawan dalam dunia pariwisata khususnya wisatawan lokal. 
4. Manfaat pariwisata dalam pembangunan ekonomi negara belum seperti yang diharapkan.

5. Berdasarkan potensi dan peluang yang ada, maka pengembangan pariwisata perlu dilakukan dalam rangka meningkatkan pertumbuhan ekonomi dengan pemberdayaan ekonomi rakyat.

6. Pengembangan sumber daya manusia di bidang pariwisata harus dilakukan secara terus menerus dan berdaya guna.

\section{Saran}

Saran yang dapat diberikan dalam esai ini adalah sebagai berikut:

1. Aktualisasi Peran Pemimpin Nasional harus ditingkatkan khususnya dalam pengembangan pariwisata.

2. Masalah-masalah pengembangan pariwisata harus diminimalisir.

3. Pemerintah harus lebih mengoptimalkan peran masyarakat dalam pengembangan pariwisata.

4. Pemimpin Nasional hendaknya memprioritaskan pengembangan sumber daya manusia di bidang pariwisata agar potensi parisiwata yang ada dapat dioptimalkan.

\section{REFERENSI}

Ashrahenny dan Sri Langgeng Ratnasari. 2016. Pengaruh Gaya Kepemimpinan dan Komunikasi Terhadap Kinerja Karyawan PT. Hi-Test (laboratory of Mechanical Testing). Jurnal Zona Manajemen. Vol. 8. No. 3. Desember 2016.

Asmarazisa, Dhenny. 2016. Pengaruh Motivasi dan Kepemimpinan Terhadap Kinerja Karyawan Pada PT. Bank BTN Batam. Jurnal Dimensi. Vol. 5. No. 2. (2016). Batam: Universitas Riau Kepulauan.

Biduan, Patris Gisau. 2016. Strategi Pengelolaan Pariwisata. Manado: Universitas Sam Ratulangi.

Darmayanti, Sri Langgeng Ratnasari. 2016. Pengaruh Gaya Kepemimpinan Dan Fasilitas Kerja Terhadap Kinerja Pegawai Pada Kantor Camat Batam Kota. Jurnal Zona Manajemen. Vol. 8. No. 1. April 206.

Febriantini. 2012. Pengembangan Pariwisata. Bandung: Widyatama.

Gaspersz, Vincent. 2007. Organizational Excellence. Jakarta: Gramedia.

Lembaga Ketahanan Nasional Republik Indonesia. Modul Bidang Studi Kepemimpinan. 2016. Jakarta: Lemhannas RI.

Pangestu, Maria Elka. 2015. Geopolitik Pariwisata Indonesia Dalam Menyongsong MEA. Jakarta: GIPI.

Wasla, Elvina dan Sri Langgeng Ratnasari. 2016. Pengaruh Gaya Kepemimpinan Dan Motivasi Terhadap Kinerja Karyawan PT. Citra Pembina Pengangkutan Industries Batam. Eksekutif Jurnal Nasional Manajemen Bisnis. Vol. 13. No.1. Juni 2016. 